Article

\title{
Effect of Barium Addition on Hydrolytic Enzymatic Activities in Food Waste Degradation under Anaerobic Conditions
}

\author{
Fuad Ale ${ }^{1}\left(\mathbb{D}\right.$, Roberto Castro-Muñoz ${ }^{2} \mathbb{D}$, Blanca Estela Barragán-Huerta $^{1} \mathbb{D}$ and \\ Odín Rodríguez-Nava ${ }^{1, * \text { (D) }}$ \\ 1 Escuela Nacional de Ciencias Biológicas, Instituto Politécnico Nacional, Avenida Wilfrido Massieu s/n, \\ Unidad Profesional Adolfo López Mateos, México City 07738, Mexico; falee1000@alumno.ipn.mx (F.A.); \\ bbarraganh@ipn.mx (B.E.B.-H.) \\ 2 Tecnologico de Monterrey, Campus Toluca, Avenida Eduardo Monroy Cárdenas 2000, \\ San Antonio Buenavista, Toluca de Lerdo 50110, Mexico; food.biotechnology88@gmail.com \\ * Correspondence: crodriguezna@ipn.mx; Tel.: +52-55-5729-6000 (ext. 52301)
}

Received: 4 October 2020; Accepted: 25 October 2020; Published: 29 October 2020

\begin{abstract}
Enzymatic hydrolysis of complex components of residual materials, such as food waste, is a rate-limiting step that conditionates the production rate of biofuels. Research into the anaerobic degradation of cellulose and starch, which are abundant components in organic waste, could contribute to optimize biofuels production processes. In this work, a lab-scale anaerobic semi-continuous hydrolytic reactor was operated for 171 days using food waste as feedstock; the effect of $\mathrm{Ba}^{2+}$ dosage over the activity of five hydrolytic enzymes was also evaluated. No significant effects were observed on the global performance of the hydrolytic process during the steady-state of the operation of the reactor, nevertheless, it was detected that $\mathrm{Ba}^{2+}$ promoted $\beta$-amylases activity by $76 \%$, inhibited endoglucanases and $\alpha$-amylases activity by 39 and $20 \%$, respectively, and had no effect on $\beta$-glucosidases and glucoamylases activity. The mechanisms that rule the observed enzymatic activity changes remain unknown; however, the discussion in this paper provides hypothetical explanations for further research.
\end{abstract}

Keywords: cellulases; amylases; food waste; enzymatic hydrolysis; anaerobic digestion

\section{Introduction}

Food wastes (FW) are relevant constituents of municipal solid waste in most countries; for instance, this type of waste represents approximately from $32-56 \%_{\mathrm{W}}\left(\%_{\mathrm{W}}\right.$ stands for weight percentage $)$ of the total municipal solid waste, depending on the effectivity of production and distribution methods, income level and consumption habits in every country [1,2]. FW have chemical properties that turn them into one of the primary sources of global water, soil and air pollutants during its microbial degradation in landfills and unregulated final disposal sites [3,4]. Even though some regions of the world have advanced on FW minimization by increasing the effectivity of food supply chains and adopting valorization technology, most developing countries are still dealing with social and economic barriers to face the management problem $[5,6]$.

Edible and non-edible cereals, fruits, vegetables and their derivatives, mainly generated as the result of loss and wasting during production, processing, packaging, distribution and consumption, represent approximately $44.9-90.0 \%{ }_{\mathrm{W}}$ of FW [5,7]. The dry mass of FW is predominantly composed by structural carbohydrates, including cellulose, hemicellulose and starch, as well as lignin, proteins and fats $[5,8]$. To select and design an appropriate valorization technology, it is important to consider the chemical composition of FW. 
Anaerobic treatment is a particularly interesting process which can be applied for FW energetic valorization due to its direct and indirect benefits; feasible FW management with biogas generation for clean energy production and the chance of using the digestate as fertilizer. A large amount of scientific research has been performed to determine the characteristics of FW as feedstock for anaerobic digestion as well as to elucidate the conditions that enhance the methane yield of the process and avoid possible inhibitions [5]. To date, different strategies, such as selecting the reactor configuration, separating the process into two stages, applying co-digestion and employing pre-treatments have been the main scopes of research [7]. Separating the process in two stages (hydrolytic-acetogenic stage and methanogenic stage) is a particularly interesting strategy with the potential advantages of increasing the methane yield of the global process and providing resilience to the system [9]; however, the cost of two equipment is slightly more expensive than one-stage systems [10]. This fact shows that it is interesting to optimize the biological process.

The previous mentioned strategies have allowed us to achieve high volatile solids conversion levels (72-96\%) and high methane yields (364-546 L/kg VS) during mesophilic anaerobic digestion of FW, nevertheless, the retention times are still far from optimal, varying from 16-78 days [7]. To increase the solids utilization rate, other strategies, such as additives dosage, aimed to increase hydrolytic enzymatic activity may be applied. For example, there has been interest in studying the effect of trace elements on anaerobic digestion, in the literature there are several studies that report the effect of metals (e.g., $\mathrm{Ba}^{2+}, \mathrm{Co}^{2+}, \mathrm{Fe}^{2+}, \mathrm{Ni}^{2+}$ and $\mathrm{Mo}^{2+}$ ) dosage over $\mathrm{FW}$ anaerobic digestion [11-15]. The results of these studies show that even at the same doses, the metals stimulate or inhibit methane yield.

As is well known, the anaerobic digestion of solid waste is carried out in four main steps: hydrolysis, acidogenesis, acetogenesis and methanogenesis, hydrolysis being the rate-limiting stage of the process in steady-state $[16,17]$. Hydrolysis is a process which is carried out by different exoenzymes segregated by hydrolytic microorganisms, important groups of these exoenzymes during anaerobic digestion of FW are cellulolytic enzymes, such as endoglucanases (EC 3.2.1.4), $\beta$-glucosidases (EC 3.2.1.21), and amylolytic enzymes as $\alpha$-amylases (EC 3.2.1.1), $\beta$-amylases (EC 3.2.1.2) and glucoamylases (EC 3.2.1.3), the activity of these enzymes determine the performance of the hydrolytic stage.

Endoglucanases catalyze the hydrolysis of $\beta-1,4$ bonds in non-crystalline regions of cellulose, and their activity is important for other cellulases to perform their function [18]. $\alpha$-amylases catalyze the hydrolysis of random $\alpha-1,4$ bonds in amylose and amylopectin (constituents of starch) [19]; on the other hand, $\beta$-amylases catalyze the hydrolysis of the second $\alpha-1,4$ bond of non-reducing ends in amylose and amylopectin [19].

There is evidence showing that alkaline earth metal ions as trace elements play an important role in the action of cellulolytic and amylolytic enzymes produced by different aerobic and anaerobic bacteria; for instance, $\mathrm{Ca}^{2+}$ is generally described as an important allosteric activator of microbial $\alpha$-amylases [20]; the activity of these enzymes is widely reported as Ca-dependent due to the thermal stabilization effect that the metal provides [21]; the effects of other alkaline earth metals on amylases activity are less studied. Regarding cellulases, Forano et al. (1994) [22] observed that the endoglucanase produced by Fibrobacter succinogenes required $\mathrm{Ca}^{2+}$ and $\mathrm{Mg}^{2+}$ to express any activity, and EDTA had an inhibitory effect. Ahmed et al. (2009) [23] suggested that the endoglucanase produced by Clostridium thermocellum is a metalloenzyme, which utilizes $\mathrm{Ca}^{2+}$ and/or $\mathrm{Mg}^{2+}$ as cofactors. Chang et al. (2016) [24] demonstrated that a cellulase, with endoglucanase activity produced by Geobacillus sp., had binding sites for $\mathrm{Ca}^{2+}$ and $\mathrm{Mg}^{2+}$ associated with thermostability of the enzyme, and the addition of these metals assisted to keep high activity values in thermophilic conditions. Similarly, Schröder et al. (2018) [25] found and studied an endoglucanase activated by $\mathrm{Ca}^{2+}$ and $\mathrm{Mg}^{2+}$, present in the metagenome derived from a mesophilic biogas plant for biomass treatment. Jeng et al. (2019) [26] studied the crystalline structure of an endoglucanase from Clostridium thermocellum, the authors found that the enzyme contained two binding sites for $\mathrm{Ca}^{2+}$, which participate in the functionality of the carbohydrate-binding module and the catalytic domain of the enzyme. 
Previously reported results for the activity stimulation of cellulases and amylases produced by different pure bacterial strains are presented in Tables 1 and 2, respectively. In general, concentrations greater than $5 \mathrm{mM}$ of $\mathrm{Ca}^{2+}, \mathrm{Mg}^{2+}$ or $\mathrm{Ba}^{2+}$ decrease the enzymatic activity of endoglucanases, except with enzymes produced by Bacillus vallismortis [27] and another uncultured microorganism from soil [28]. Among these studies are those carried out by several authors [23,29-31], who showed that alkaline earth metals might have an effect over important cellulolytic and amylolytic enzymes produced by anaerobic bacteria strains (e.g., Clostridium thermocellum, Lactobacillus amylovorus, Ruminobacter amylophilus and Geobacillus thermoleovorans).

Table 1. Effect of alkaline earth metal ions over enzymatic activity of pure bacterial endoglucanases.

\begin{tabular}{|c|c|c|c|c|}
\hline Metal & Concentration (mM) & Activity Stimulation (\%) & Bacterial Strain & Ref. \\
\hline \multirow{2}{*}{$\mathrm{Mg}$} & 2.0 & 20 & \multirow{6}{*}{ Paenibacillus sp. } & \multirow{6}{*}{ [32] } \\
\hline & 5.0 & -10 & & \\
\hline \multirow[b]{2}{*}{$\mathrm{Ca}$} & 2.0 & 20 & & \\
\hline & 5.0 & 10 & & \\
\hline \multirow{2}{*}{$\mathrm{Ba}$} & 2.0 & 51 & & \\
\hline & 5.0 & -20 & & \\
\hline $\mathrm{Mg}$ & 1.0 & 29 & \multirow{3}{*}{ Lysobacter sp. } & \multirow{3}{*}{ [33] } \\
\hline $\mathrm{Ca}$ & 1.0 & 30 & & \\
\hline $\mathrm{Ba}$ & 1.0 & 30 & & \\
\hline \multirow[b]{2}{*}{$\mathrm{Ba}$} & 1.0 & 0 & \multirow{2}{*}{$\begin{array}{l}\text { Uncultured } \\
\text { microorganism from soil }\end{array}$} & \multirow[b]{2}{*}{ [28] } \\
\hline & 10.0 & 54 & & \\
\hline $\mathrm{Mg}$ & 2.0 & 48 & \multirow{3}{*}{ Bacillus agaradhaerens } & \multirow{3}{*}{ [34] } \\
\hline $\mathrm{Ca}$ & 2.0 & 50 & & \\
\hline $\mathrm{Sr}$ & 2.0 & 45 & & \\
\hline \multirow{7}{*}{$\mathrm{Mg}$} & 1.0 & 50 & \multirow{12}{*}{ Clostridium thermocellum } & \multirow{12}{*}{ [23] } \\
\hline & 2.0 & 80 & & \\
\hline & 6.0 & 70 & & \\
\hline & 10.0 & 40 & & \\
\hline & 25.0 & 0 & & \\
\hline & 35.0 & -70 & & \\
\hline & 50.0 & -100 & & \\
\hline \multirow{5}{*}{$\mathrm{Ca}$} & 2.0 & 0 & & \\
\hline & 4.0 & 30 & & \\
\hline & 6.0 & 80 & & \\
\hline & 8.0 & 10 & & \\
\hline & 10.0 & -80 & & \\
\hline $\mathrm{Mg}$ & 1.0 & 46 & \multirow{4}{*}{ Bacillus cellulyticus } & \multirow{4}{*}{ [35] } \\
\hline Mg & 2.0 & 101 & & \\
\hline \multirow{2}{*}{$\mathrm{Ca}$} & 1.0 & 40 & & \\
\hline & 2.0 & 54 & & \\
\hline \multirow{2}{*}{$\mathrm{Mg}$} & 5.0 & 46 & \multirow{4}{*}{ Bacillus vallismortis } & \multirow{4}{*}{ [27] } \\
\hline & 10.0 & 75 & & \\
\hline \multirow{2}{*}{$\mathrm{Ca}$} & 5.0 & 56 & & \\
\hline & 10.0 & 84 & & \\
\hline \multirow{2}{*}{$\mathrm{Mg}$} & 5.0 & 31 & \multirow{4}{*}{$\begin{array}{l}\text { Uncultured anaerobe } \\
\text { from a biogas plant }\end{array}$} & \multirow{4}{*}{ [25] } \\
\hline & 10.0 & 2 & & \\
\hline & 5.0 & 40 & & \\
\hline $\mathrm{Ca}$ & 10.0 & 31 & & \\
\hline $\mathrm{Mg}$ & 5.0 & -11 & Uncultured anaerobe & {$[36]$} \\
\hline $\mathrm{Ca}$ & 5.0 & 14 & from yak rumen & [36] \\
\hline
\end{tabular}


Table 2. Effect of alkaline earth metals over enzymatic activity of pure bacterial $\alpha$-amylases.

\begin{tabular}{|c|c|c|c|c|}
\hline Metal & Concentration (mM) & $\alpha$-Amylases Stimulation (\%) & Bacterial Strain & Ref. \\
\hline $\mathrm{Ca}$ & 5.0 & 80 & \multirow{2}{*}{ Geobacillus sp. } & \multirow{2}{*}{ [37] } \\
\hline $\mathrm{Ba}$ & 5.0 & 63 & & \\
\hline \multirow{2}{*}{$\mathrm{Ca}$} & 1.0 & 0 & \multirow{6}{*}{$\begin{array}{l}\text { Geobacillus } \\
\text { thermoleovorans }\end{array}$} & \multirow{6}{*}{ [31] } \\
\hline & 5.0 & 0 & & \\
\hline \multirow{2}{*}{$\mathrm{Mg}$} & 1.0 & 73 & & \\
\hline & 5.0 & 0 & & \\
\hline \multirow{2}{*}{$\mathrm{Ba}$} & 1.0 & 124 & & \\
\hline & 5.0 & 0 & & \\
\hline \multirow{3}{*}{$\mathrm{Ca}$} & 1.0 & 0 & \multirow{9}{*}{ Bacillus sp. } & \multirow{9}{*}[38]{} \\
\hline & 5.0 & -10 & & \\
\hline & 10.0 & -10 & & \\
\hline \multirow{3}{*}{$\mathrm{Mg}$} & 1.0 & 0 & & \\
\hline & 5.0 & 0 & & \\
\hline & 10.0 & 10 & & \\
\hline \multirow{3}{*}{$\mathrm{Ba}$} & 1.0 & 15 & & \\
\hline & 5.0 & 0 & & \\
\hline & 10.0 & 15 & & \\
\hline \multirow{2}{*}{$\mathrm{Ca}$} & 0.5 & 5 & \multirow{8}{*}{$\begin{array}{c}\text { Bacillus } \\
\text { stearothermophilus }\end{array}$} & \multirow{8}{*}{ [39] } \\
\hline & 1.0 & 22 & & \\
\hline \multirow{2}{*}{$\mathrm{Mg}$} & 0.5 & -8 & & \\
\hline & 1.0 & -15 & & \\
\hline \multirow{2}{*}{$\mathrm{Sr}$} & 0.5 & 0 & & \\
\hline & 1.0 & 12 & & \\
\hline \multirow{2}{*}{$\mathrm{Ba}$} & 0.5 & 0 & & \\
\hline & 1.0 & 15 & & \\
\hline $\mathrm{Ca}$ & 5.0 & -21 & \multirow{4}{*}{ Bacillus circulans } & \multirow{4}{*}{ [40] } \\
\hline $\mathrm{Mg}$ & 5.0 & -18 & & \\
\hline $\mathrm{Sr}$ & 5.0 & -28 & & \\
\hline $\mathrm{Ba}$ & 5.0 & -22 & & \\
\hline \multirow{3}{*}{$\begin{array}{c}\mathrm{Ca} \\
\mathrm{Mg} \\
\mathrm{Ba}\end{array}$} & 2.0 & 27 & \multirow{3}{*}{$\begin{array}{l}\text { Uncultured } \\
\text { microorganism }\end{array}$} & \multirow{3}{*}{ [41] } \\
\hline & 2.0 & -42 & & \\
\hline & 2.0 & -28 & & \\
\hline & 1.0 & 2 & & \\
\hline $\mathrm{Ca}$ & 5.0 & 0 & & \\
\hline $\mathrm{Mg}$ & 1.0 & 0 & Bacillus licheniformis & [42] \\
\hline $\mathrm{Mg}$ & 5.0 & 5 & Bacilus licheniformis & [42] \\
\hline & 1.0 & -5 & & \\
\hline $\mathrm{Ba}$ & 5.0 & -11 & & \\
\hline $\mathrm{Ca}$ & 5.0 & -66 & & \\
\hline $\mathrm{Mg}$ & 5.0 & -52 & Bacillus sp. & [43] \\
\hline $\mathrm{Ba}$ & 5.0 & -39 & & \\
\hline & 5.0 & 40 & & \\
\hline $\mathrm{Ca}$ & 10.0 & 100 & & \\
\hline & 5.0 & -40 & Geobacillus sp & {$[44]$} \\
\hline Mg & 10.0 & -60 & Geobacillus sp. & [44] \\
\hline & 5.0 & -10 & & \\
\hline $\mathrm{Ba}$ & 10.0 & -20 & & \\
\hline
\end{tabular}


Food waste itself contain traces of Ba; for instance, Jansson et al. [45] reported an approximate concentration of this metal of $0.36 \mathrm{~mm}$ in the digestate of a large-scale dry anaerobic digester fed with municipal FW. There are less studies related to $\mathrm{Ba}^{2+}$ than other alkaline earth metal ions; several authors $[28,31-33,37-39]$ showed that under certain conditions, $\mathrm{Ba}^{2+}$ can stimulate enzymatic catalysis conducted by cellulases and amylases; however, the effect of this metal over the hydrolytic stage of anaerobic digestion has not yet been elucidated. Recently, Wyman et al. [12] found that $\mathrm{Ba}^{2+}$ dosages higher than $1.46 \mathrm{~mm}$ have an important inhibitory effect over cellulose hydrolysis and methane yield in batch anaerobic digestion of dried green fodder. Nevertheless, there is still the need to explain the phenomena involved in the previously observed effects of the metal ion over hydrolytic activity.

With the purpose of gaining more insight about the effect of $\mathrm{Ba}$ on the hydrolytic process in anaerobic conditions, the main aim of the present study was to determine if $\mathrm{Ba}^{2+}$ dosage $(1.0 \mathrm{~mm})$ could significantly promote the volumetric activity of endoglucanases, $\beta$-glucosidases, $\alpha$-amylases, $\beta$-amylases and glucoamylases in a mesophilic anaerobic semi-continuous hydrolytic reactor (ASHR) using plant-based FW as substrate. This is one of the first studies reporting the activity of specific groups of cellulases and amylases in a lab-scale ASHR fed with FW in steady state.

\section{Materials and Methods}

\subsection{Analytical Methods}

\subsubsection{Solids and Moisture}

A gravimetric method was employed to measure the moisture content in FW and hydrolytic inoculum making use of an analytical balance (Precisa ${ }^{\circledR}$ XR305A, Dietikon, Zúrich, Switzerland), the FW were dehydrated in an oven at $55 \pm 5{ }^{\circ} \mathrm{C}$ for 4 days while the hydrolytic inoculum was dehydrated at $100 \pm 5{ }^{\circ} \mathrm{C}$ for $24 \mathrm{~h}$, the results were reported as wet basis percentage $\left(\%_{\mathrm{wb}}\right)$. The volatile solids (VS) content of the feedstock and inoculum was determined by triplicate according to a previously described method [46], the results were reported as dry basis percentage $\left(\%_{\mathrm{db}}\right)$. The values of free moisture and volatile solids for the feedstock and hydrolytic inoculum are shown in Table 3.

Table 3. Moisture and volatile solids content in feedstock and inoculum.

\begin{tabular}{ccc}
\hline & Free Moisture $\left(\mathbf{\%}_{\mathbf{w b}}\right)$ & Volatile Solids $\left(\mathbf{\%}_{\mathbf{d b}}\right)$ \\
\hline Food waste (feedstock) & 88.57 & $74.81 \pm 2.22$ \\
Hydrolytic inoculum & $98.65 \pm 0.06$ & $82.39 \pm 3.8$ \\
\hline & + Standard deviation
\end{tabular}

\subsubsection{Soluble Chemical Oxygen Demand and $\mathrm{pH}$}

To estimate the amount of organic matter solubilized by the hydrolytic process the soluble chemical oxygen demand (sCOD) of the inlet and outlet of the ASHR was quantified. The SCOD was measured with the potassium dichromate spectrometric method as indicated in previously described methods [47]. The samples were centrifuged at 14,000 rpm (Sigma ${ }^{\circledR} 1-14$, Osterode am Harz, Germany) for $15 \mathrm{~min}$, then the supernatant was removed and SCOD was measured. The amount of organic matter solubilized by the hydrolytic processes during the operation of the ASHR was estimated as the difference of the sCOD in the outlet and the SCOD in the inlet of the reactor.

$\mathrm{pH}$ was measured on the AHSR outlet with a Thermo Scientific ${ }^{\mathrm{TM}}$ Orion $^{\mathrm{TM}}$ 3-Star Benchtop $\mathrm{pH}$ Meter (Waltham, MA, USA).

\subsubsection{Volumetric Enzymatic Activity}

Volumetric enzymatic activities of two cellulases (Endoglucanases and $\beta$-glucosidases) and three amylases ( $\alpha$-amylases, $\beta$-amylases and Glucoamylases) were measured through spectrophotometric techniques before and after $\mathrm{Ba}^{2+}$ dosage. These enzymatic assays have been described by different 
authors (Table 4). One volumetric enzymatic activity unit was defined as $1 \mu \mathrm{mol}$ of the expected product of the enzyme, generated per min of reaction time, per $\mathrm{mL}$ of reaction volume $(\mathrm{U} / \mathrm{mL}[=] \mu \mathrm{mol} / \mathrm{min} / \mathrm{mL})$.

Table 4. Conditions for enzymatic assays and reference methods.

\begin{tabular}{|c|c|c|c|c|c|}
\hline Enzyme & Model Substrate & $\begin{array}{l}\text { Expected } \\
\text { Product }\end{array}$ & $\begin{array}{c}\text { Reaction Time } \\
\text { and Temperature } \\
\left(\mathrm{min},{ }^{\circ} \mathrm{C}\right)\end{array}$ & $\begin{array}{l}\text { Buffer Data } \\
(\mathrm{pH}, \mathrm{mM})\end{array}$ & Ref. \\
\hline $\begin{array}{l}\text { Endoglucanases } \\
\quad(3.2 .1 .3)\end{array}$ & $\begin{array}{l}\text { Carboxymethyl cellulose } \\
\text { (Merck }{ }^{\circledR} \text { C4888) }\end{array}$ & D-Glucose ${ }^{1}$ & 30,50 & $\begin{array}{l}\text { Citrates } \\
(4.8,0.050)\end{array}$ & [48] \\
\hline $\begin{array}{c}\beta \text {-glucosidases } \\
(3.2 .1 .21)\end{array}$ & $\begin{array}{c}p \text {-Nitro-phenyl } \\
\beta \text {-D-glucopyranoside } \\
\text { (Merck }{ }^{\circledR} 292710 \text { ) }\end{array}$ & $p$-Nitro-phenol ${ }^{3}$ & 30,50 & $\begin{array}{l}\text { Acetate } \\
(4.8,0.050)\end{array}$ & [49] \\
\hline $\begin{array}{c}\alpha \text {-amylases } \\
(3.2 .1 .1)\end{array}$ & $\begin{array}{l}\text { Maize amylopectin } \\
\left(\text { Merck }^{\circledR} 10120\right)\end{array}$ & Maltose $^{2}$ & 30,20 & $\begin{array}{l}\text { Phosphates } \\
(6.9,0.020)\end{array}$ & [50] \\
\hline $\begin{array}{c}\beta \text {-amylases } \\
(3.2 .1 .2)\end{array}$ & $\begin{array}{l}\text { Maize amylopectin } \\
\left.\text { (Merck }{ }^{\circledR} 10120\right)\end{array}$ & Maltose $^{2}$ & 30,20 & $\begin{array}{c}\text { Acetate } \\
(4.8,0.016)\end{array}$ & [50] \\
\hline $\begin{array}{c}\text { Glucoamylases } \\
\quad(3.2 .1 .91)\end{array}$ & $\begin{array}{l}\text { Soluble starch } \\
\text { (Merck }{ }^{\circledR} \text { S9765) }\end{array}$ & D-Glucose ${ }^{1}$ & 30,40 & $\begin{array}{l}\text { Acetate } \\
(4.5,0.100)\end{array}$ & [51] \\
\hline
\end{tabular}

${ }^{1}$ Measured by DNS technique described by Ghose (1987) [48] with D-Glucose $(0.0-2.0 \mathrm{~g} / \mathrm{L})$ standard curve $\left(\mathrm{R}^{2}>0.99\right)$;

${ }^{2}$ Measured by DNS technique described by Ghose (1987) [48] with Maltose $(0.0-1.0 \mathrm{~g} / \mathrm{L})$ standard curve $\left(\mathrm{R}^{2}>0.99\right)$;

${ }^{3}$ Measured by the technique described by Magalhães et al. (2006) [49] with a $p$-Nitrophenol (0.0-1.0 mM) standard curve $\left(R^{2}>0.99\right)$.

The samples from the reactor were centrifuged at 14,000 rpm (Sigma $\left.{ }^{\circledR} 1-14\right)$ for $15 \mathrm{~min}$ prior analysis. The products of the enzymatic reactions were quantified according to the specified methods, with a spectrophotometer HACH ${ }^{\circledR}$ DR 5000 UV/V (Loveland, CO, USA). Standard curves, spectrum zeros and sample blanks were always prepared and run together with the samples. The sample blanks consisted on identically treated test tubes but with the addition of the sample after the enzymatic reaction was stopped, as suggested by Forouhi and Gunn [52], to minimize the interference provided by the soluble substances in the sample. Dilution of samples was not required as the concentration of the reaction products was always inside the interval of the standard curves. Every sample was analyzed by triplicate and the reaction time was carefully monitored for every single replicate.

\subsection{Obtention, Analysis and Pretreatment of Feedstock and Inoculum}

The food wastes used in the study were collected from a restaurant located in the north part of Mexico City (19.4758 N, 99.1314 W) in three batches and then combined. The FW were segregated considering the categories suggested by the Food and Agriculture Organization of United Nations (FAO) [53], which were also adopted by other authors [5,7], the collected FW were mainly composed by fruits, vegetables and cereals derivatives $\left(85 \%_{\mathrm{wb}}\right)$, bones, meat, grease and egg husks $\left(14 \%_{\mathrm{wb}}\right)$ and other non-organic waste $\left(1 \%_{\mathrm{wb}}\right)$. Only fruits, vegetables and cereals derivatives were maintained in the FW before pretreatment to favor the development of cellulolytic and amylolytic microorganisms while using the waste as feedstock during experimentation.

In total, $58 \mathrm{~kg}$ of FW was collected in three different batches and then dehydrated, shredded with a laboratory blender (Waring ${ }^{\circledR}$ HGBSS, Torrington, CT, USA) to a maximum particle size of $2 \mathrm{~mm}$ (verified with a sieve), combined and manually homogenized to get only one feedstock to be used in the hole experiment in order to minimize experimental variations due to changes in the composition of the feedstock as drastic variations in the microbial community in the reactor. The FW were contained as a single in a resealable plastic bag and preserved at $4{ }^{\circ} \mathrm{C}$. After pretreatment, the volatile solids (VS) content of the feedstock was determined.

The material utilized to inoculate the AHSR for experimentation consisted of hydrolysate from a stabilized lab-scale mesophilic anaerobic hydrolytic reactor with 199 days of previous operation. This reactor was originally inoculated with donkey manure, daily fed with FW $(0.47 \mathrm{~g} \mathrm{VS} / \mathrm{L} / \mathrm{d})$, and maintained at $\mathrm{pH} 5.87 \pm 0.07$ (standard deviation). Three samples of the inoculum were subjected to moisture and volatile solids gravimetry determinations. 


\subsection{ASHR Configuration and Operation Protocol}

A 4 L Kimax ${ }^{\circledR}$ (Milville, NJ, USA) beaker was used as a vessel for the ASHR and it was blown in order to horizontally flatten its upper edge to make the use of a flange-form acrylic top possible, as pointed by an arrow in Figure 1. The top of the ASHR had a $24 \mathrm{~cm}$ diameter and had three orifices; one to take out and take in material from and to the reactor, another to conduct the gas output, and the last one for temperature monitoring. All connections located on the top of the reactor were fixed by cable glands and then covered with hot-melt adhesive silicon with the aim of preventing gas leaks. Furthermore, the ASHR vessel was surrounded by a $3.1 \mathrm{~cm}$ (internal diameter) silicon hose connected to a hot water recirculation stream with a semi-automatic temperature control system $\left(35 \pm 1.5^{\circ} \mathrm{C}\right.$ as setpoint). Continuous stir was provided by a $7.6 \mathrm{~cm}$ magnetic bar $(160 \mathrm{rpm})$. Figure 1 illustrates the ASHR and the parts of the systems described above.

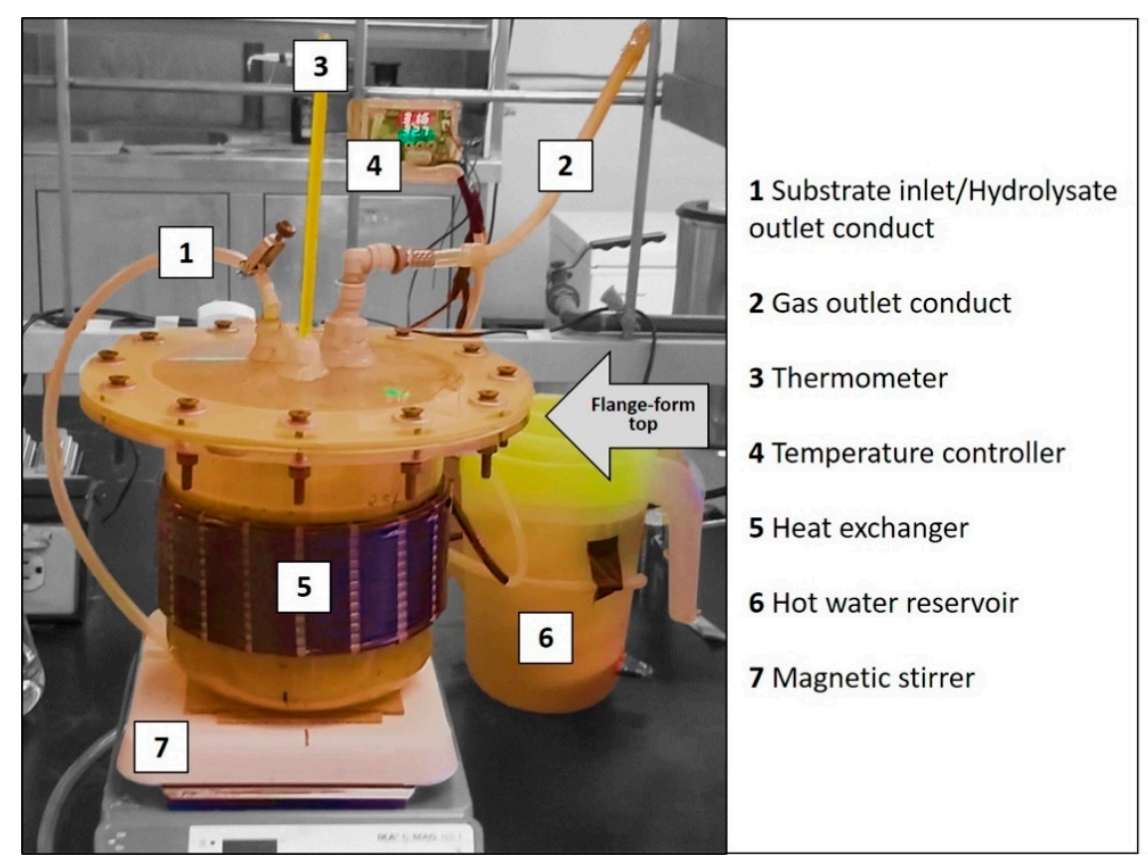

Figure 1. Anaerobic semi-continuous hydrolytic reactor configuration used during experimentation.

At the beginning of the operation of the ASHR, it was inoculated for the only time with $2.90 \mathrm{~g}$ SV/L of hydrolytic inoculum. The ASHR was operated on a daily basis following a feeding protocol; $110 \mathrm{~mL}$ of the homogeneous hydrolysate were gathered from the reactor, the hydrolysate was processed for later sCOD and $\mathrm{pH}$ analysis, and then the mix of FW and alkaline solution (previously dissolved $\mathrm{NaHCO}_{3}$ in the loading rate indicated in Table 5) was introduced to the reactor. The total volume of this mixture was equal to the necessary required to maintain constant the wet volume of $2.5 \mathrm{~L}$ in the reactor.

Table 5. Summary of ASHR operation stages.

\begin{tabular}{cccccc}
\hline & Stage & Operation Days & OLR (g VS/L/d) & $\begin{array}{c}\text { NaHCO }_{3} \text { Loading } \\
\text { Rate (g/L/d) }\end{array}$ & $\begin{array}{c}\text { Ba }^{2+} \text { Dosage } \\
(\mathbf{m m o l} / \mathbf{L})\end{array}$ \\
\hline \multirow{4}{*}{ Conditioning } & 1 & $0-21$ & 0.52 & 0.10 & - \\
& 2 & $22-34$ & 1.00 & 0.10 & - \\
& 3 & $35-67$ & 1.50 & 0.11 & - \\
\hline \multirow{2}{*}{ Evaluation } & 4 & $68-123$ & 2.00 & 0.15 & 0.0 \\
& 5 & $124-153$ & 2.00 & 0.15 & 1.0 \\
\hline
\end{tabular}




\subsection{ASHR Operation Stages, Monitoring and Evaluation of the Effect of $\mathrm{Ba}^{2+}$ over the Hydrolytic Process}

During conditioning of the anaerobic semi-continuous hydrolytic reactor, the organic loading rate (OLR) provided by FW was gradually increased from $0.52-2.00 \mathrm{gVS} / \mathrm{L} / \mathrm{d}$, alkaline solution was added to prevent the $\mathrm{pH}$ from reaching values below 5 . During reactor operation, sCOD and $\mathrm{pH}$ were measured by triplicate. The $\mathrm{sCOD}$ generated by hydrolysis $\left(\mathrm{sCOD}_{\mathrm{GH}}\right)$ in the system was measured as the difference between sCOD Outlet and sCOD Inlet (Equation (1)) similarly to other authors $[54,55]$.

$$
\mathrm{sCOD}_{\mathrm{GH}}=\mathrm{sCOD}_{\text {Outlet }}-\mathrm{sCOD}_{\text {Inlet }}
$$

When the steady-state was reached in the ASHR, the $\mathrm{Ba}^{2+}$ was added to reach a theoretical metal concentration in the reactor of $1.0 \mathrm{mM}(137 \mathrm{mg} / \mathrm{L})$ in two days. In Table 5, a summary of the ASHR operation stages is shown.

A non-linear regression line and its confidence interval for the $\mathrm{pH}$ and SCOD results were obtained in accordance with the locally estimated scatterplot smoothing (LOESS) method. To evaluate the effect of $\mathrm{Ba}^{2+}$ on volumetric enzymatic activities and sCOD before and after $\mathrm{Ba}^{2+}$ dosage during the steady-state of the operation of the ASHR (stage 5), Tukey's multiple range test was used to compare the means. Differences among the means of $p<0.01$ were considered significant. The statistical tests were computed using R V.4.0.0 using the HSD.test function from the Agricolae package.

\section{Results}

\subsection{Anaerobic Semi-Continuous Hydrolytic Reactor Operation}

To evaluate the effect of $\mathrm{Ba}^{2+}(1.0 \mathrm{~mm})$ in anaerobic hydrolytic of $\mathrm{FW}$, the ASHR was previously stabilized gradually increasing the OLR until $2 \mathrm{~g} \mathrm{VS} / \mathrm{L} / \mathrm{d}$. The adaptation of the system was achieved after of 124 days of operation. Figure 2 shows the $\mathrm{pH}$ and sCOD behavior along the stages of operation of the reactor; these results are summarized in Table 6. At the first stage of operation, the $\mathrm{pH}$ value was 6.19 and gradually decreased to 5.01 for the stage 4 , after this time until the end of reactor operation, the $\mathrm{pH}$ increased slightly from $5.01 \pm 0.02$ to $5.13 \pm 0.01$ (Figure 2A). Figure $2 \mathrm{~B}$ shows the sCOD values of both the inlet and outlet of the reactor. These values increased along the conditioning stages (1-4) and remained constant after 124 days of operation, during the evaluation stage the average sCOD value in the inlet was $11.41 \pm 0.26 \mathrm{~g} / \mathrm{L}$ while in the outlet was $26.62 \pm 0.31 \mathrm{~g} / \mathrm{L}$, the $\mathrm{sCOD}_{\mathrm{GH}}$ in the system due to microbial activity in steady-state was $15.22 \mathrm{~g} / \mathrm{L}$.

The changes during the first four stages of operation were driven by the gradual increase in the OLR, within a period of 68 days. Then, the OLR was kept constant and the system was allowed to reach a steady-state, using the behavior and variation coefficient of $\mathrm{pH}$ and $\mathrm{sCOD}$ along time as indicators of steadiness. The adaptation of the system to the higher OLR lasted 56 days and, after that, the operation of the ASHR continued the operation continued for 30 days to establish a baseline for evaluation. After that, a constant daily dose of the metal was supplied to the ASHR to maintain that concentration.

Table 6. Summary of monitoring results along ASHR operation.

\begin{tabular}{ccccc}
\hline Stage & $\mathrm{pH}$ & $\mathrm{sCOD}_{\text {Inlet }}(\mathrm{g} / \mathrm{L})$ & $\mathrm{sCOD}_{\text {Outlet }}(\mathrm{g} / \mathrm{L})$ & sCOD Generated by Hydrolysis $(\mathrm{g} / \mathrm{L})$ \\
\hline 1 & $6.19 \pm 0.05$ & $3.10 \pm 0.22$ & $5.41 \pm 0.99$ & 2.32 \\
2 & $5.78 \pm 0.10$ & $6.22 \pm 0.60$ & $9.14 \pm 1.27$ & 2.92 \\
3 & $5.32 \pm 0.07$ & $8.33 \pm 0.14$ & $12.40 \pm 0.79$ & 4.07 \\
4 & $5.01 \pm 0.02$ & $11.12 \pm 0.25$ & $20.81 \pm 0.65$ & 9.69 \\
5 & $5.13 \pm 0.01$ & $11.41 \pm 0.26$ & $26.62 \pm 0.31$ & 15.22 \\
\hline \multicolumn{5}{c}{ \pm Confidence interval $(\alpha=95 \%)}$.
\end{tabular}



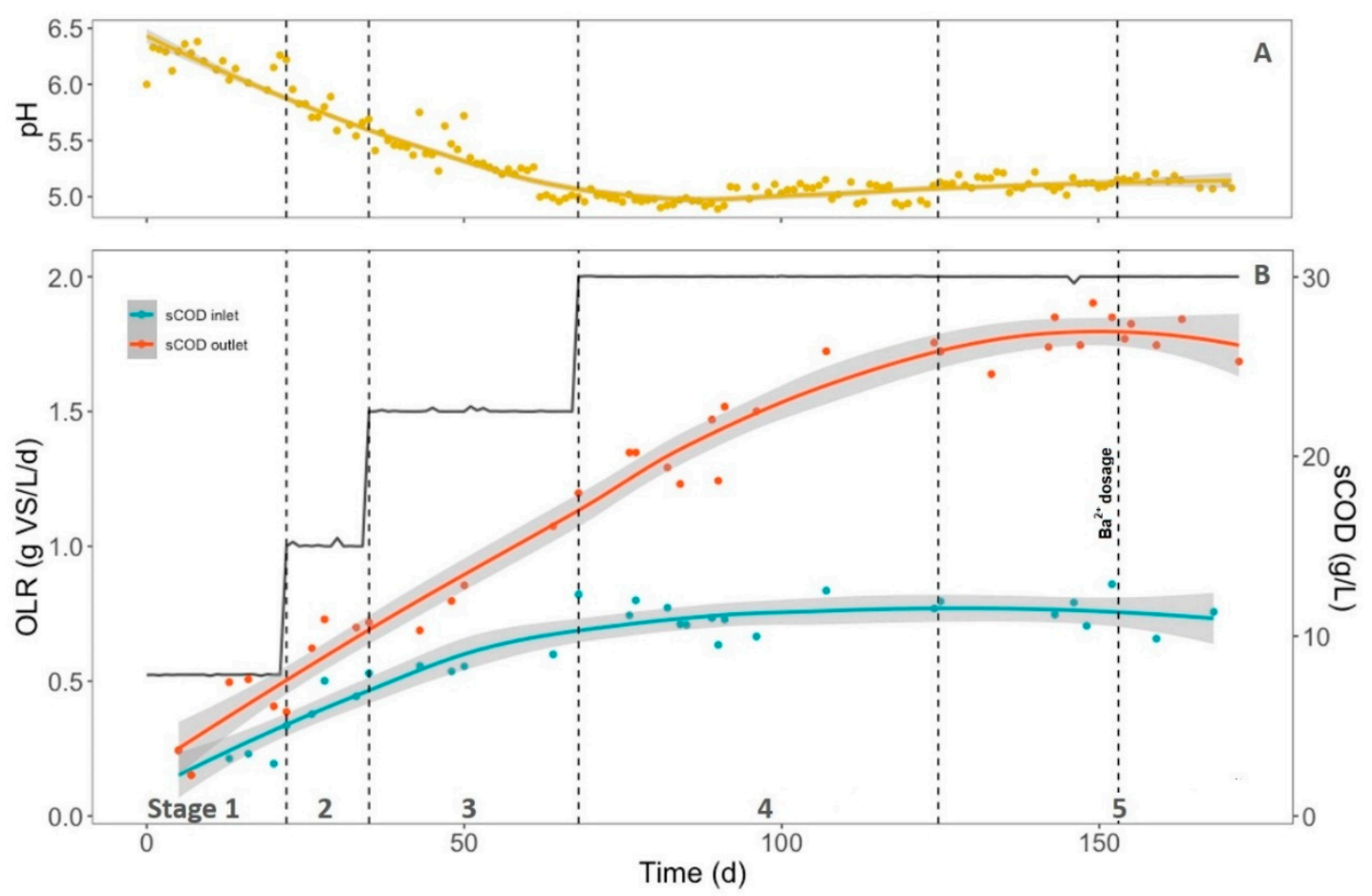

Figure 2. Organic loading rate (OLR) along the operation of the anaerobic semi-continuous hydrolytic reactor (ASHR) and monitoring results. (A- $-\mathrm{pH}$ results, $\mathbf{B}-\mathrm{OLR}$ and soluble chemical oxygen demand (sCOD) results. The grey areas represent the confidence interval of the non-linear regression line).

\subsection{Effect of $\mathrm{Ba}^{2+}$ over the Glucosidases Enzymatic Activity}

The effect of $\mathrm{Ba}^{2+}$ on volumetric activities of endoglucanases, $\beta$-glucosidases, $\alpha$-amylases, $\beta$-amylases and glucoamylases was evaluated during stage 5 in the ASHR. After the steady-state was reached (on day number 124), on day number 154 of the operation of the reactor, $\mathrm{Ba}^{2+}(1.0 \mathrm{mM})$ was supplied, before and after this time the volumetric activities were measured by triplicate. The enzymatic activity results are displayed in Figure $3 \mathrm{~B}, \mathrm{C}$ together with the $\mathrm{SCOD}_{\text {Outlet }}$ values obtained from the ASHR in the same operation time (Figure 3A). Activity stimulation was calculated for each enzyme, taking the activity before $\mathrm{Ba}^{2+}$ dosage as reference. The significance of the stimulation was determined by means of Tukey's multiple range test method. As shown in Table 8, there were significant differences after $\mathrm{Ba}^{2+}$ dosage only in three of the five studied groups of enzymes; a negative sign on activity stimulations indicates inhibition. Moreover, no perceptible change in the outlet sCOD was observed.

Table 7. Activity values and significance for the different studied enzyme groups.

\begin{tabular}{cccccc}
\hline Enzyme Group & Enzyme Name & $\begin{array}{c}\text { Enzymatic } \\
\text { Activity Before } \\
\mathbf{b a}^{2+} \text { Dosage } \\
\mathbf{( U / m L )}\end{array}$ & $\begin{array}{c}\text { Enzymatic } \\
\text { Activity after } \\
\mathbf{B a}^{2+} \text { Dosage } \\
\mathbf{( U / m L )}\end{array}$ & $\begin{array}{c}\text { Activity } \\
\text { Stimulation } \\
\mathbf{( \% )}\end{array}$ & $p$ \\
\hline \multirow{2}{*}{ Cellulases } & Endoglucanases & $32.77 \pm 4.58^{*}$ & $19.98 \pm 2.64^{*}$ & -39.05 & $4.1 \times 10^{-5}$ \\
& $\beta$-glucosidases & $20.25 \pm 3.24$ & $17.20 \pm 2.14$ & -15.04 & $8.9 \times 10^{-2}$ \\
\hline \multirow{2}{*}{ Amylases } & $\alpha$-amylases & $82.19 \pm 3.89 *$ & $65.79 \pm 7.88^{*}$ & -19.95 & $5.4 \times 10^{-4}$ \\
& $\beta$-amylases & $51.41 \pm 4.99 *$ & $90.23 \pm 15.17^{*}$ & +75.51 & $9.0 \times 10^{-6}$ \\
& Glucoamylases & $472.11 \pm 56.54$ & $529.32 \pm 23.35$ & +12.12 & $6.3 \times 10^{-2}$ \\
\hline
\end{tabular}

* Shows significant differences $(p<0.01) ; \pm$ Standard deviation. 


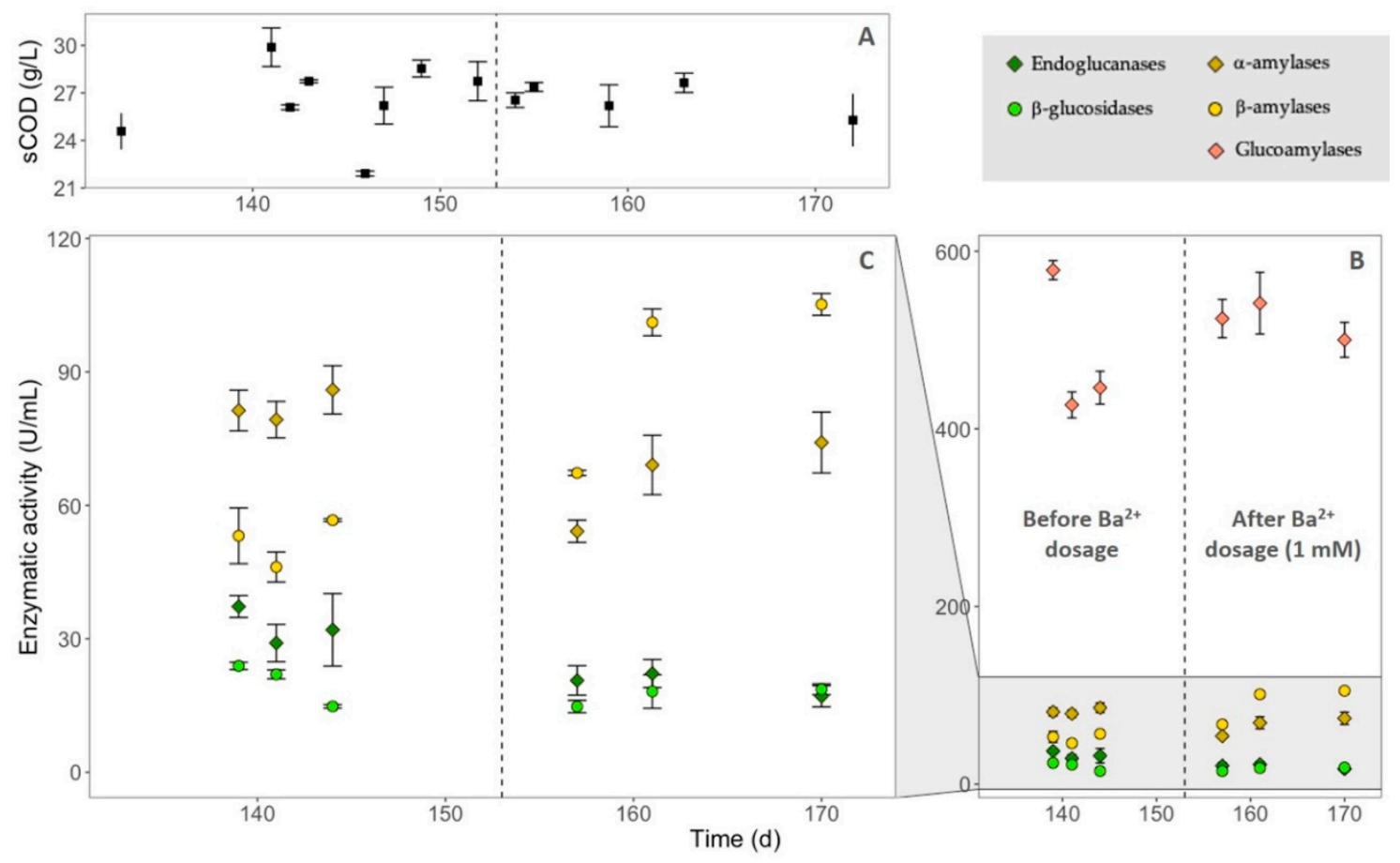

Figure 3. Effect of $\mathrm{Ba}^{2+}$ dosage over enzymatic activities and sCOD in the ASHR, error bars indicate standard deviation of three replicates, the dotted vertical line indicates the beginning of barium dosage (A.-Outlet sCOD in the ASHR in steady-state, B.-Activity results for the five studied enzymes, C.-Close up on the activity results with lower values).

Table 8. Activity values and significance for the different studied enzyme groups.

\begin{tabular}{cccccc}
\hline Enzyme Group & Enzyme Name & $\begin{array}{c}\text { Enzymatic } \\
\text { Activity Before } \\
\mathbf{b a}^{2+} \text { Dosage } \\
\mathbf{( U / m L )}\end{array}$ & $\begin{array}{c}\text { Enzymatic } \\
\text { Activity after } \\
\mathbf{B a}^{2+} \text { Dosage } \\
\mathbf{( U / m L )}\end{array}$ & $\begin{array}{c}\text { Activity } \\
\text { Stimulation } \\
\mathbf{( \% )}\end{array}$ & $p$ \\
\hline \multirow{2}{*}{ Cellulases } & Endoglucanases & $32.77 \pm 4.58^{*}$ & $19.98 \pm 2.64^{*}$ & -39.05 & $4.1 \times 10^{-5}$ \\
& $\beta$-glucosidases & $20.25 \pm 3.24$ & $17.20 \pm 2.14$ & -15.04 & $8.9 \times 10^{-2}$ \\
\hline \multirow{2}{*}{ Amylases } & $\alpha$-amylases & $82.19 \pm 3.89 *$ & $65.79 \pm 7.88^{*}$ & -19.95 & $5.4 \times 10^{-4}$ \\
& $\beta$-amylases & $51.41 \pm 4.99 *$ & $90.23 \pm 15.17^{*}$ & +75.51 & $9.0 \times 10^{-6}$ \\
& Glucoamylases & $472.11 \pm 56.54$ & $529.32 \pm 23.35$ & +12.12 & $6.3 \times 10^{-2}$ \\
\hline
\end{tabular}

* Shows significant differences $(p<0.01) ; \pm$ Standard deviation.

\section{Discussion}

\subsection{Anaerobic Semi-Continuous Hydrolytic Reactor Operation}

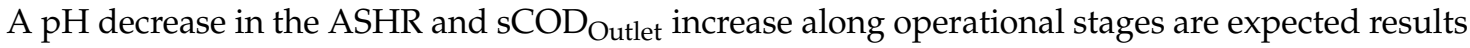
due to the acid $\mathrm{pH}$ of the feedstock itself [5] and the volatile fatty acids accumulation phenomenon conducted by acidogenic microbes [56]. Thus, the $\mathrm{pH}$ and sCOD behavior observed in Figure 2 suggests the development of anaerobic hydrolytic and acidogenic microbial communities in the reactor. This is an undesired process for methane production purposes in one-stage anaerobic digestion, but is useful for promoting the hydrolytic-acidogenic microorganisms prevalence in the first step of the two-stage systems [9,57].

Throughout the operation, the SCOD in the ASHR outlet considerably differed from the inlet; this fact evidences the solubilization of the complex compounds of the feedstock by hydrolysis in the equipment [58]. As presented in Table 6, the $\mathrm{sCOD}_{\mathrm{GH}}$ in the ASHR at steady-state was higher than the feedstock sCOD contributionl; this fact suggests that the structural carbohydrates in FW have more 
potential for biofuels production than the soluble substances of the crude feedstock solely, as previously observed by Zhang et al. (2017) [58], who developed and studied a three-stage anaerobic digester with enhanced hydrolysis. On the other hand, since FW have a high content of soluble organics with potential for methane production and the enhancement of cellulose and starch hydrolytic process demands additional investment, there is still a lack of research to determine the economic feasibility of enzymatic hydrolysis optimization at large-scale anaerobic digestion facilities.

\subsection{Effects of $\mathrm{Ba}^{2+}$ over the Hydrolytic Process of Food Waste}

To provide a fair discussion, three general considerations were taken during the analysis of the results, and their specific implications are described throughout this section:

- Enzymes purification was not conducted, and due to the lack of effective manners to differentiate specific activities of substrate-sharing enzymes, it is difficult to ensure that activity measurements did not include contributions from various groups of enzymes.

- Activities reported in this work represent a maximum rate of catalysis that the enzymes produced by anaerobes in the ASHR could conduct during an enzymatic assay with non-limiting substrate concentration and optimum conditions, the reported values do not mean to represent sugars production in the reactor.

- Previous observations of the effect of metal ions over the activity of hydrolytic enzymes, which were produced by isolated bacterial strains, are not representative of the microbial communities developed in the ASHR, nevertheless, these observations are the most abundant comparison points; therefore, they were carefully considered for possible explanations of the obtained results, raising hypothesis for subsequent research.

According to the results reported in Figure 3 and Table 8, endoglucanases and $\alpha$-amylases were significantly inhibited, while $\beta$-amylases were significantly stimulated after $\mathrm{Ba}^{2+}$ dosage, nevertheless, the hydrolysis level in the ASHR, did not suffer any perceptible change. These observations indicate that $\mathrm{Ba}^{2+}$ dosage did not trigger any substantial effect over the global hydrolytic process and probably the perturbations on the different enzymatic activities were compensated between each other, exhibiting an apparent non perturbation on the SCOD in the ASHR outlet. However, the inclusion of more specific and sensible response variables (e.g., fermentable sugars or volatile fatty acids concentrations) might be considered for future studies to provide a better assessment of the changes in the global hydrolytic process.

In relation to the studied cellulases, a significant endoglucanases inhibition in the ASHR of around $39 \%$ after $\mathrm{Ba}^{2+}$ dosage was observed (Table 1 ). Endoglucanases catalyze the hydrolysis of $\beta-1,4$ bonds in non-crystalline regions of cellulose, and their activity is important for other cellulases to perform their function [18]; thus, an inhibition of these enzymes implicates a decrease in the cellulose hydrolysis rate of the system. This particular result is in agreement with Wyman et al. results [12]; the authors found that there was a relationship between $\mathrm{Ba}^{2+}$ concentration and a selective inhibition of the hydrolysis stage of batch anaerobic digestion of cellulose, the metal significantly affected the process when soluble concentrations between $6.8-21.5 \mathrm{~mm}$ are reached. They found evidence that their observations may be linked with an indirect disturbance; $\mathrm{Ba}^{2+}$ modifies the solubility chemical equilibrium of $\mathrm{Zn}$ in the sludge of the reactor, making it more bioavailable to potentially reach toxic levels in the medium. This inhibition mechanism implicates that $\mathrm{Ba}^{2+}$ induces an indirect toxic effect only over hydrolytic microorganisms, or at least selectively interferes in hydrolytic functions. However, another possible inhibition mechanism, considering the significant direct interactions of the metal ion with cellulolytic enzymes, is proposed in the present work.

As shown in Table 1 and described in the introduction of the present work, several reports have reported different results when analyzing the effect of Group II elements (alkaline earth metals) over cellulases activity from several bacterial strains, those observations suggest that is very likely that 
these metals interact directly with bacterial endoglucanases, having an inhibitory effect only at high concentrations (approximately $>5 \mathrm{~mm}$ ), varying from one producer organism to another.

It is important to mention that the concentration of barium in the ASHR, provided by the feedstock and inoculum, was not considered in the present work; therefore, the total $\mathrm{Ba}^{2+}$ concentration in the reactor could be higher than $1.0 \mathrm{mM}$. This is an important issue to be considered in future research, since heterogeneous equilibrium phenomena lead to interesting changes in the metal ions concentration in an anaerobic reactor [12]. It is not still possible to determine the direct endoglucanases inhibition mechanism by $\mathrm{Ba}^{2+}$ in anaerobic digestion; however, given the present enzymatic activity results (Table 8 ) and previous observations (Table 1), it is possible to preliminary discard the competitive and irreversible inhibition types [59]. Given the above, it is also possible to hypothesize that, even though the alkaline earth metal ions are required for endoglucanases action, in soluble concentrations higher that $5 \mathrm{mM}$, they could present an inhibitory effect led by non-competitive and/or uncompetitive mechanisms during cellulose enzymatic hydrolysis in anaerobic conditions.

Regarding the studied amylases, it is estimated that the activity of $\alpha$-amylases in the ASHR before $\mathrm{Ba}^{2+}$ dosage was approximately $12.84 \mu \mathrm{mol}_{\text {Maltose }} / \mathrm{min} / \mathrm{g}$ volatile solid suspended (VSS). Other authors [60] reported a considerably higher value for amylases activity (ca. $684 \mu \mathrm{mol}_{\text {Maltose }} / \mathrm{min} / \mathrm{g}$ VSS) in the mesophilic anaerobic digestion of the organic fraction of municipal solid waste; in addition, the authors managed a higher OLR $(7.0 \mathrm{~g} \mathrm{VS} / \mathrm{L} / \mathrm{d})$ and did not discriminated the intrinsic hydrolytic activity of the fresh substrate.

According to results shown in Figure 3, glucoamylases activity was considerably higher than $\alpha$-amylases and $\beta$-amylases, with values before $\mathrm{Ba}^{2+}$ dosage around $472 \mathrm{U} / \mathrm{mL}$ (Table 8 ). This result suggests that glucoamylases were predominant in the ASHR over other amylolytic enzymes; however, this may be varied since the glucoamylases assay was performed in different conditions, i.e., higher temperature and a more soluble substrate than the $\alpha$-amylases and $\beta$-amylases assays. This was with the aim of minimizing the contributions of substrate-sharing enzymes during the experimental procedure. Nonetheless, other authors [61] also obtained higher glucoamylases activity compared with $\alpha$-amylases when investigating the enzymatic hydrolysis of FW with fungal mash.

Significant $\alpha$-amylases inhibition and $\beta$-amylases stimulation of about $20 \%$ and $76 \%$, respectively, were observed after $\mathrm{Ba}^{2+}$ dosage in the ASHR (Table 8). In principle, the first ones catalyze the hydrolysis of random $\alpha-1,4$ bonds in amylose and amylopectin [19], on the other hand, $\beta$-amylases catalyze the hydrolysis of the second $\alpha-1,4$ bond of non-reducing ends in amylose and amylopectin [19]. It is known that a significant inhibition or stimulation of these enzymes comprises a change in starch hydrolysis rate in the system; however, the effect of $\mathrm{Ba}^{2+}$ was mutually compensated between both enzymes (Figure 3C). It is usually reported that $\alpha$-amylases are stimulated or inhibited by metal ions, Table 2 enlists the effect of $\mathrm{Ba}^{2+}$ on the enzymatic activity of $\alpha$-amylases, and $\beta$-amylases produced by different bacterial strains.

To date, there is not enough evidence to establish a possible relationship between $\mathrm{Ba}^{2+}$ concentration (in the range of $0.5-10.0 \mathrm{~mm}$ ) and the inhibition or stimulation of $\alpha$-amylases and $\beta$-amylases; thus, the effect observed in the present work might not implicate a direct interaction of the metal with those enzymes. According to previous reports (Table 2), it is likely that the producer bacterial strain and/or the culture conditions determine the amylases sensitivity to $\mathrm{Ba}^{2+}$, hence, the effect of the metal over enzymatic activity produced by the microbial community in an anaerobic reactor might require to be supported by a taxonomic characterization.

Interestingly, Srivastava [39] reported that $\mathrm{Ba}^{2+}$ at $1.0 \mathrm{mM}$ promoted the enzymatic activity of purified $\alpha$-amylases and $\beta$-amylases by 15 and $10 \%$, respectively, from Bacillus stearothermophilus. They also observed a relationship between the separate addition of $\mathrm{Ca}^{2+}, \mathrm{Ba}^{2+}$ and $\mathrm{Sr}^{2+}(0.5-5 \mathrm{~mm})$ and the elimination of a non-competitive inhibition that EDTA had over both enzymes. Several authors also reported that chelating agents induce inhibition on $\alpha$-amylases $[13,43,44]$. Consequently, further research might be focused on determining if chelating compounds produced by anaerobes 
have significant effects over $\alpha$-amylases and $\beta$-amylases activity in the presence of $\mathrm{Ba}^{2+}$; it is important to notice that the inhibition or stimulation mechanisms may vary from one enzyme to another.

During the present study, enzymatic assays were carried out using the ASHR outlet supernatant, thus, only the activity of extracellular enzymes were quantified. The quantification of cell-bound enzymes might be relevant, since they play an important role in cellulose and starch degradation conducted by anaerobes [62].

\section{Conclusions}

In this work, the effect of $\mathrm{Ba}^{2+}(1 \mathrm{mM})$ over the activity of endoglucanases, $\beta$-glucosidases, $\alpha$-amylases, $\beta$-amylases and glucoamylases during hydrolysis of food waste in an anaerobic semi-continuous hydrolytic reactor was evaluated. The reactor was operated for 171 days, the soluble chemical oxygen demand generated by microbial anaerobic hydrolytic process in steady-state was $15.22 \mathrm{~g} / \mathrm{L}$ when the reactor was fed with an organic loading rate of $2 \mathrm{~g} \mathrm{VS} / \mathrm{L} /$ day. It was observed that $\mathrm{Ba}^{2+}$ dosage at $1 \mathrm{mM}$, under the experimental conditions, had no significant effects on the overall performance of the hydrolytic process, nor on the enzymatic activity of $\beta$-glucosidases and glucoamylases with activity before $\mathrm{Ba}^{2+}$ dosage of 20.25 and $472.11 \mathrm{U} / \mathrm{mL}$, respectively. On the other hand, $\mathrm{Ba}^{2+}$ dosage inhibited endoglucanases activity from 32.77 to 19.98 (39\%), and $\alpha$-amylases from 82.19 to 65.79 $(20 \%)$, and stimulated $\beta$-amylases activity from 51.41 to $90.23(76 \%)$. Given the observations in the present work and previous research, the hypothesis that $\mathrm{Ba}^{2+}$ presents an inhibitory effect lead by non-competitive and/or uncompetitive mechanisms during cellulose enzymatic hydrolysis in anaerobic conditions was raised. This article is a first approach in the understanding of the effect of $\mathrm{Ba}^{2+}$ over the physiological processes of cellulose and starch biodegradation under anaerobic conditions, and it contributes to elucidating the effect of $\mathrm{Ba}^{2+}$ concentration on two-stage anaerobic systems.

Author Contributions: Conceptualization, F.A. and O.R.-N.; methodology, F.A., B.E.B.-H. and O.R.-N.; software, F.A.; validation, F.A. and O.R.-N.; formal analysis, F.A. and O.R.-N.; investigation, F.A. and O.R.-N.; resources, R.C.-M., B.E.B.-H. and O.R.-N.; data curation, F.A. and O.R.-N.; writing-original draft preparation, F.A. and O.R.-N.; writing-review and editing, F.A. and O.R.-N.; visualization, F.A., R.C.-M. and O.R.-N.; supervision, R.C.-M., B.E.B.-H. and O.R.-N.; project administration, F.A., B.E.B.-H. and O.R.-N.; funding acquisition, B.E.B.-H., R.C.-M. and O.R.-N. All authors have read and agreed to the published version of the manuscript.

Funding: This research was funded by Instituto Politécnico Nacional under the development of project SIP no. 20190195.

Conflicts of Interest: The authors declare no conflict of interest. The funders had no role in the design of the study; in the collection, analyses, or interpretation of data; in the writing of the manuscript, or in the decision to publish the results.

\section{References}

1. Parfitt, J.; Barthel, M.; Macnaughton, S. Food waste within food supply chains: Quantification and potential for change to 2050. Philos. Trans. R. Soc. 2010, 365, 3065-3081. [CrossRef]

2. Kaza, S.; Yao, L.; Bhada-Tata, P.; Van Woerden, F. What a Waste 2.0: A Global Snapshot of Solid Waste Management to 2050; World Bank: Washington, DC, USA, 2018; ISBN 9781464813474.

3. Ren, Y.; Yu, M.; Wu, C.; Wang, Q.; Gao, M.; Huang, Q.; Liu, Y. A comprehensive review on food waste anaerobic digestion: Research updates and tendencies. Bioresour. Technol. 2017, 247, 1069-1076. [CrossRef] [PubMed]

4. $\quad$ Bousquet, P.; Ciais, P.; Miller, J.B.; Dlugokencky, E.J.; Hauglustaine, D.A.; Prigent, C.; Van Der Werf, G.R.; Peylin, P.; Brunke, E.G.; Carouge, C.; et al. Contribution of anthropogenic and natural sources to atmospheric methane variability. Nature 2006, 443, 439-443. [CrossRef] [PubMed]

5. Fisgativa, H.; Tremier, A.; Dabert, P. Characterizing the variability of food waste quality: A need for efficient valorisation through anaerobic digestion. Waste Manag. 2016, 50, 264-274. [CrossRef] [PubMed]

6. Vögeli, Y.; Lohri, C.R.; Gallardo, A.; Diener, S.; Zurbrügg, C. Anaerobic Digestion of Biowaste in Developing Countries: Practical Information and Case Studies; Swiss Federal Institute of Aquatic Science and Technology (Eawag): Dübendorf, Switzerland, 2014; ISBN 9783906484587. 
7. Braguglia, C.M.; Gallipoli, A.; Gianico, A.; Pagliaccia, P. Anaerobic bioconversion of food waste into energy: A critical review. Bioresour. Technol. 2018, 248, 37-56. [CrossRef] [PubMed]

8. García-Gen, S.; Sousbie, P.; Rangaraj, G.; Lema, J.M.; Rodríguez, J.; Steyer, J.P.; Torrijos, M. Kinetic modelling of anaerobic hydrolysis of solid wastes, including disintegration processes. Waste Manag. 2015, 35, 96-104. [CrossRef]

9. Voelklein, M.A.; O' Shea, R.; Jacob, A.; Murphy, J.D. Role of trace elements in single and two-stage digestion of food waste at high organic loading rates. Energy 2017, 121, 185-192. [CrossRef]

10. Rajendran, K.; Mahapatra, D.; Venkatraman, A.V.; Muthuswamy, S.; Pugazhendhi, A. Advancing anaerobic digestion through two-stage processes: Current developments and future trends. Renew. Sustain. Energy Rev. 2020, 123, 109746. [CrossRef]

11. Choong, Y.Y.; Norli, I.; Abdullah, A.Z.; Yhaya, M.F. Impacts of trace element supplementation on the performance of anaerobic digestion process: A critical review. Bioresour. Technol. 2016, 209, 369-379. [CrossRef]

12. Wyman, V.; Serrano, A.; Borja, R.; Jiménez, A.; Carvajal, A.; Lenz, M.; Bartacek, J.; Fermoso, F.G. Effects of barium on the pathways of anaerobic digestion. J. Environ. Manag. 2019, 232, 397-403. [CrossRef]

13. Facchin, V.; Cavinato, C.; Fatone, F.; Pavan, P.; Cecchi, F.; Bolzonella, D. Effect of trace element supplementation on the mesophilic anaerobic digestion of foodwaste in batch trials: The influence of inoculum origin. Biochem. Eng. J. 2013, 70, 71-77. [CrossRef]

14. Zhang, W.; Zhang, L.; Li, A. Enhanced anaerobic digestion of food waste by trace metal elements supplementation and reduced metals dosage by green chelating agent [S, S]-EDDS via improving metals bioavailability. Water Res. 2015, 84, 266-277. [CrossRef] [PubMed]

15. Zhang, L.; Lee, Y.-W.; Jahng, D. Anaerobic co-digestion of food waste and piggery wastewater: Focusing on the role of trace elements. Bioresour. Technol. 2011, 102, 5048-5059. [CrossRef] [PubMed]

16. Zhang, C.; Su, H.; Baeyens, J.; Tan, T. Reviewing the anaerobic digestion of food waste for biogas production. Renew. Sustain. Energy Rev. 2014, 38, 383-392. [CrossRef]

17. Mata-Alvarez, J.; Macé, S.; Llabrés, P. Anaerobic digestion of organic solid wastes. An overview of research achievements and perspectives. Bioresour. Technol. 2000, 74, 3-16. [CrossRef]

18. Lübeck, M. (Ed.) Cellulases: Methods and Protocols, Methods in Molecular Biology; Springer Science+Business Media, LCC Part of Springer Nature: Copenhagen, Denmark, 2018; Volume 1796, ISBN 9781493978762.

19. Whitaker, J.R. Principles of Enzymology for the Food Sciences; Routledge: New York, NY, USA, 1994; pp. $391-415$.

20. Souza, P.M.D. Application of microbial $\alpha$-amylase in industry-A review. Braz. J. Microbiol. 2010, 41, 850-861. [CrossRef]

21. Gupta, R.; Gigras, P.; Mohapatra, H.; Goswami, V.K.; Chauhan, B. Microbial $\alpha$-amylases: A biotechnological perspective. Process Biochem. 2003, 38, 1599-1616. [CrossRef]

22. Forano, E.; Broussolle, V.; Gaudet, G.; Bryant, J.A. Molecular cloning, expression, and characterization of a new endoglucanase gene from Fibrobacter succinogenes S85. Curr. Microbiol. 1994, 28, 7-14. [CrossRef]

23. Ahmed, S.; Deka, D.; Jawed, M.; Goyal, D.; Fontes, C.M.G.A.; Goyal, A. Biochemical characterization of a recombinant derivative (CtLic26A-Cel5) of a cellulosomal cellulase from Clostridium thermocellum. Curr. Trends Biotechnol. Pharm. 2009, 3, 56-63.

24. Chang, C.-J.; Lee, C.-C.; Chan, Y.-T.; Trudeau, D.L.; Wu, M.-H.; Tsai, C.-H.; Yu, S.-M.; Ho, T.-H.D.; Wang, A.H.-J.; Hsiao, C.-D.; et al. Exploring the mechanism responsible for cellulase thermostability by structure-guided recombination. PLoS ONE 2016, 11, e0147485. [CrossRef]

25. Schröder, C.; Burkhardt, C.; Busch, P.; Schirrmacher, G.; Claren, J.; Antranikian, G. Characterization of a theme $\mathrm{C}$ glycoside hydrolase family 9 endo-beta-glucanase from a biogas reactor metagenome. Protein J. 2018, 37, 454-460. [CrossRef] [PubMed]

26. Jeng, W.-Y.; Liu, C.-I.; Lu, T.-J.; Lin, H.-J.; Wang, N.-C.; Wang, A.H.-J. Crystal Structures of the C-terminally truncated endoglucanase Cel9Q from clostridium thermocellum complexed with cellodextrins and tris. ChemBioChem 2019, 20, 295-307. [CrossRef] [PubMed]

27. Gaur, R.; Tiwari, S. Isolation, production, purification and characterization of an organic-solvent-thermostable alkalophilic cellulase from Bacillus vallismortis RG-07. BMC Biotechnol. 2015, 15, 1-12. [CrossRef] [PubMed]

28. Muñoz, C.; Fermoso, F.G.; Rivas, M.; González Grau, J.M. Hydrolytic enzyme activity enhanced by Barium supplementation. AIMS Microbiol. 2016, 2, 402-411. [CrossRef] 
29. Lim, J.W.; Chen, C.L.; Ho, I.J.R.; Wang, J.Y. Study of microbial community and biodegradation efficiency for single- and two-phase anaerobic co-digestion of brown water and food waste. Bioresour. Technol. 2013, 147, 193-201. [CrossRef]

30. McWethy, S.J.; Hartman, P.A. Purification and some properties of an extracellular alpha amylase from Bacteroides amylophilus. J. Bacteriol. 1977, 129, 1537-1544. [CrossRef]

31. Uma Maheswar Rao, J.L.; Satyanarayana, T. Purification and characterization of a hyperthermostable and high maltogenic $\alpha$-amylase of an extreme thermophile Geobacillus thermoleovorans. Appl. Biochem. Biotechnol. 2007, 142, 179-193. [CrossRef]

32. Lee, J.P.; Kim, Y.A.; Kim, S.K.; Kim, H. Characterization of a multimodular endo- $\beta$-1,4-glucanase (Cel9K) from paenibacillus sp. $\mathrm{x} 4$ with a potential additive for saccharification. J. Microbiol. Biotechnol. 2018, 28, 588-596. [CrossRef] [PubMed]

33. Ogura, J.; Toyoda, A.; Kurosawa, T.; Chong, A.L.; Chohnan, S.; Masaki, T. Purification, characterization, and gene analysis of cellulase (Cel8A) from Lysobacter sp. IB-9374. Biosci. Biotechnol. Biochem. 2006, 70, 2420-2428. [CrossRef]

34. Hirasawa, K.; Uchimura, K.; Kashiwa, M.; Grant, W.D.; Ito, S.; Kobayashi, T.; Horikoshi, K. Salt-activated endoglucanase of a strain of alkaliphilic Bacillus agaradhaerens. Antonie van Leeuwenhoek 2006, 89, 211-219. [CrossRef]

35. Lee, T.-K.; Kim, C.-H. Molecular cloning and expression of an endo- $\beta-1,4-D-$ glucanase I (Avicelase I) gene from Bacillus cellulyticus K-12 and characterization of the recombinant enzyme. Appl. Biochem. Biotechnol. Part A Enzym. Eng. Biotechnol. 1999, 80, 121-140. [CrossRef]

36. Bao, L.; Huang, Q.; Chang, L.; Zhou, J.; Lu, H. Screening and characterization of a cellulase with endocellulase and exocellulase activity from yak rumen metagenome. J. Mol. Catal. B Enzym. 2011, 73, 104-110. [CrossRef]

37. Dheeran, P.; Kumar, S.; Jaiswal, Y.K.; Adhikari, D.K. Characterization of hyperthermostable $\alpha$-amylase from Geobacillus sp. IIPTN. Appl. Microbiol. Biotechnol. 2010, 86, 1857-1866. [CrossRef] [PubMed]

38. Asoodeh, A.; Chamani, J.; Lagzian, M. A novel thermostable, acidophilic $\alpha$-amylase from a new thermophilic "Bacillus sp. Ferdowsicous" isolated from Ferdows hot mineral spring in Iran: Purification and biochemical characterization. Int. J. Biol. Macromol. 2010, 46, 289-297. [CrossRef]

39. Srivastava, R.A.K. Purification and chemical characterization of thermostable amylases produced by Bacillus stearothermophilus. Enzyme Microb. Technol. 1987, 9, 749-754. [CrossRef]

40. Takasaki, Y. An amylase producing maltotetraose and maltopentaose from Bacillus circulans. Agric. Biol. Chem. 1983, 47, 2193-2199. [CrossRef]

41. Vester, J.K.; Glaring, M.A.; Stougaard, P. An exceptionally cold-adapted alpha-amylase from a metagenomic library of a cold and alkaline environment. Appl. Microbiol. Biotechnol. 2015, 99, 717-727. [CrossRef]

42. Wu, X.; Wang, Y.; Tong, B.; Chen, X.; Chen, J. Purification and biochemical characterization of a thermostable and acid-stable alpha-amylase from Bacillus licheniformis B4-423. Int. J. Biol. Macromol. 2018, 109, 329-337. [CrossRef]

43. Bernhardsdotter, E.C.M.J.; Ng, J.D.; Garriott, O.K.; Pusey, M.L. Enzymic properties of an alkaline chelator-resistant $\alpha$-amylase from an alkaliphilic Bacillus sp. isolate L1711. Process Biochem. 2005, 40, 2401-2408. [CrossRef]

44. Mollania, N.; Khajeh, K.; Hosseinkhani, S.; Dabirmanesh, B. Purification and characterization of a thermostable phytate resistant $\alpha$-amylase from Geobacillus sp. LH8. Int. J. Biol. Macromol. 2010, 46, 27-36. [CrossRef] [PubMed]

45. Jansson, A.T.; Patinvoh, R.J.; Horváth, I.S.; Taherzadeh, M.J. Dry anaerobic digestion of food and paper industry wastes at different solid contents. Fermentation 2019, 5, 40. [CrossRef]

46. Meng, Y.; Li, S.; Yuan, H.; Zou, D.; Liu, Y.; Zhu, B.; Li, X. Effect of lipase addition on hydrolysis and biomethane production of Chinese food waste. Bioresour. Technol. 2015, 179, 452-459. [CrossRef]

47. APHA; AWWA. Standard Methods for Examination of Water and Wastewater, 22nd ed.; Rice, E.W., Baird, R.B., Eaton, A.D., Clesceri, L.S., Eds.; American Public Health Association, American Water Works Association, Water Environment Federation: Denver, CO, USA, 2012.

48. Ghose, T.K. Measurement of cellulase activities. Pure Appl. Chem. 1987, 59, 257-268. [CrossRef]

49. Magalhães, P.O.; Ferraz, A.; Milagres, A.F.M. Enzymatic properties of two $\beta$-glucosidases from Ceriporiopsis subvermispora produced in biopulping conditions. J. Appl. Microbiol. 2006, 101, 480-486. [CrossRef] [PubMed] 
50. Bernfeld, P. Amylases, alpha and beta. Methods Enzymol. 1955, 1, 149-158.

51. Fogarty, W.M.; Benson, C.P. Purification and properties of a thermophilic amyloglucosidase from aspergillus niger. Eur. J. Appl. Microbiol. Biotechnol. 1983, 18, 271-278. [CrossRef]

52. Forouhi, E.; Gunn, D.J. Some effects of metal ions on the estimation of reducing sugars in biological media. Biotechnol. Bioeng. 1983, XXV, 1905-1911. [CrossRef] [PubMed]

53. Gustavsson, J.; Cederberg, C.; Sonesson, U.; Van Otterdijk, R.; Meybeck, A. Global Food Losses and Food Waste -Extent, Causes and Prevention; Food and Agriculture Organization of the United Nations: Rome, Italy, 2011; ISBN 978-92-5-107205-9.

54. Kim, J.; Park, C.; Kim, T.H.; Lee, M.; Kim, S.; Kim, S.W.; Lee, J. Effects of various pretreatments for enhanced anaerobic digestion with waste activated sludge. J. Biosci. Bioeng. 2003, 95, 271-275. [CrossRef]

55. Kumar Biswal, B.; Huang, H.; Dai, J.; Chen, G.H.; Wu, D. Impact of low-thermal pretreatment on physicochemical properties of saline waste activated sludge, hydrolysis of organics and methane yield in anaerobic digestion. Bioresour. Technol. 2020, 297, 122423. [CrossRef]

56. Ahring, B.K. Perspectives for Anaerobic Digestion. In Biomethanation I. Advances in Biochemical Engineering/Biotechnology; Springer: Berlin/Heidelberg, Germany, 2003; Volume 81, pp. 1-30.

57. Ariunbaatar, J.; Di Perta, E.S.; Panico, A.; Frunzo, L.; Esposito, G.; Lens, P.N.L.; Pirozzi, F. Effect of ammoniacal nitrogen on one-stage and two-stage anaerobic digestion of food waste. Waste Manag. 2015, 38, 388-398. [CrossRef]

58. Zhang, J.; Loh, K.-C.; Li, W.; Lim, J.W.; Dai, Y.; Tong, Y.W. Three-stage anaerobic digester for food waste. Appl. Energy 2017, 194, 287-295. [CrossRef]

59. Melo, V.; Cuamatzi, O. Bioquímica de los Procesos Metabólicos, 2nd ed.; Reverté: Ciudad de México, Mexico, 2008; ISBN 9789686708615.

60. Kim, H.-W.; Nam, J.-Y.; Kang, S.-T.; Kim, D.-H.; Jung, K.-W.; Shin, H.-S. Hydrolytic activities of extracellular enzymes in thermophilic and mesophilic anaerobic sequencing-batch reactors treating organic fractions of municipal solid wastes. Bioresour. Technol. 2012, 110, 130-134. [CrossRef]

61. Uçkun Kiran, E.; Liu, Y. Bioethanol production from mixed food waste by an effective enzymatic pretreatment. Fuel 2015, 159, 463-469. [CrossRef]

62. Lynd, L.R.; Weimer, P.J.; van Zyl, W.H.; Pretorius, I.S. Microbial Cellulose Utilization: Fundamentals and Biotechnology. Microbiol. Mol. Biol. Rev. 2002, 66, 506-577. [CrossRef]

Publisher's Note: MDPI stays neutral with regard to jurisdictional claims in published maps and institutional affiliations.

(C) 2020 by the authors. Licensee MDPI, Basel, Switzerland. This article is an open access article distributed under the terms and conditions of the Creative Commons Attribution (CC BY) license (http://creativecommons.org/licenses/by/4.0/). 